\title{
A theoretical study on the mass input and output and energy of the biomedical waste incinerator
}

\author{
Sari Jaber ${ }^{1}$, Alaa Aldin Aljawad ${ }^{1}$, Tudor Prisecaru ${ }^{1}$ and Elena Pop $^{1, *}$ \\ ${ }^{1}$ University Politehnica of Bucharest, Faculty of Mechanical Engineering and Mechatronics, \\ Romania,
}

\begin{abstract}
Medical waste production has increased with many government and private hospitals and health centres due to the increase in the population, especially in the spread of Coronavirus Covid-19. This increase in medical waste is treating in medical incinerators. One of the advantages of incineration is the reduction of volume, weight and energy recovery. This paper examines the medical waste incinerator of one of the Medical City hospitals in Baghdad, as this incinerator internally divided into primary and secondary chambers. The medical waste for yellow bags placed in the primary chamber is burned with the help of air and a burner of $178-356 \mathrm{~kW}$, resulting in waste burned. Then the combustion products pass through the secondary chamber, wherewith air and another burner of $178-356 \mathrm{~kW}$, the combustion of gases and volatile materials from the waste completed. Air is then supplied to the flue gases to dilute the emission concentrations and reduce the flue gas temperature. This paper presents a study on the inputs and outputs of waste, air, fuel and the advantage of the heat quantity generated from the combustion of biomedical waste. As a result of this theoretical work, this incinerator provides an acceptable and durable solution to waste disposal problems and the risks of spreading viruses today.
\end{abstract}

\section{Introduction}

Medical waste has increased due to the increase in the population [1][2], especially in the spread of Coronavirus Covid-19 as the quantities of waste increased due to the frequent use of protective clothing and for all people. In the incineration process, waste treated to reduce the volume of waste by about $90 \%$, weight by about $70 \%$, disinfection, energy recapture, detoxification, and resource recapture [3][4][5][6]. Incineration is a practically reliable method of waste treatment. It is currently the best treatment method at present, especially from the third month of 2020. Incinerators have proven the efficiency of their work and the rapid disposal of medical waste [7]. The advantages of incineration treating become clearer. Medical waste completely burned at high temperatures of $1200^{\circ} \mathrm{C}$, and high temperatures

\footnotetext{
* Corresponding author: elena.pop@upb.ro
} 
must be under controlled to ensure complete combustion to reduce environmental and health pollution. The results of waste incineration are flue gases and residual ash.

\section{Materials and Methods}

\subsection{Medical waste incineration}

There are three types of incinerators for treating biomedical waste: Multiple-chamber [8], Controlled air, Rotary kiln [9], and Mobil incinerator [10].

\subsection{Specifications of the medical waste incinerator}

The incinerator used in this study is the air-controlled type of incineration to treat a mixture of yellow bags of medical waste with a capacity of $100 \mathrm{~kg}$ per hour, shown in fig 1 .

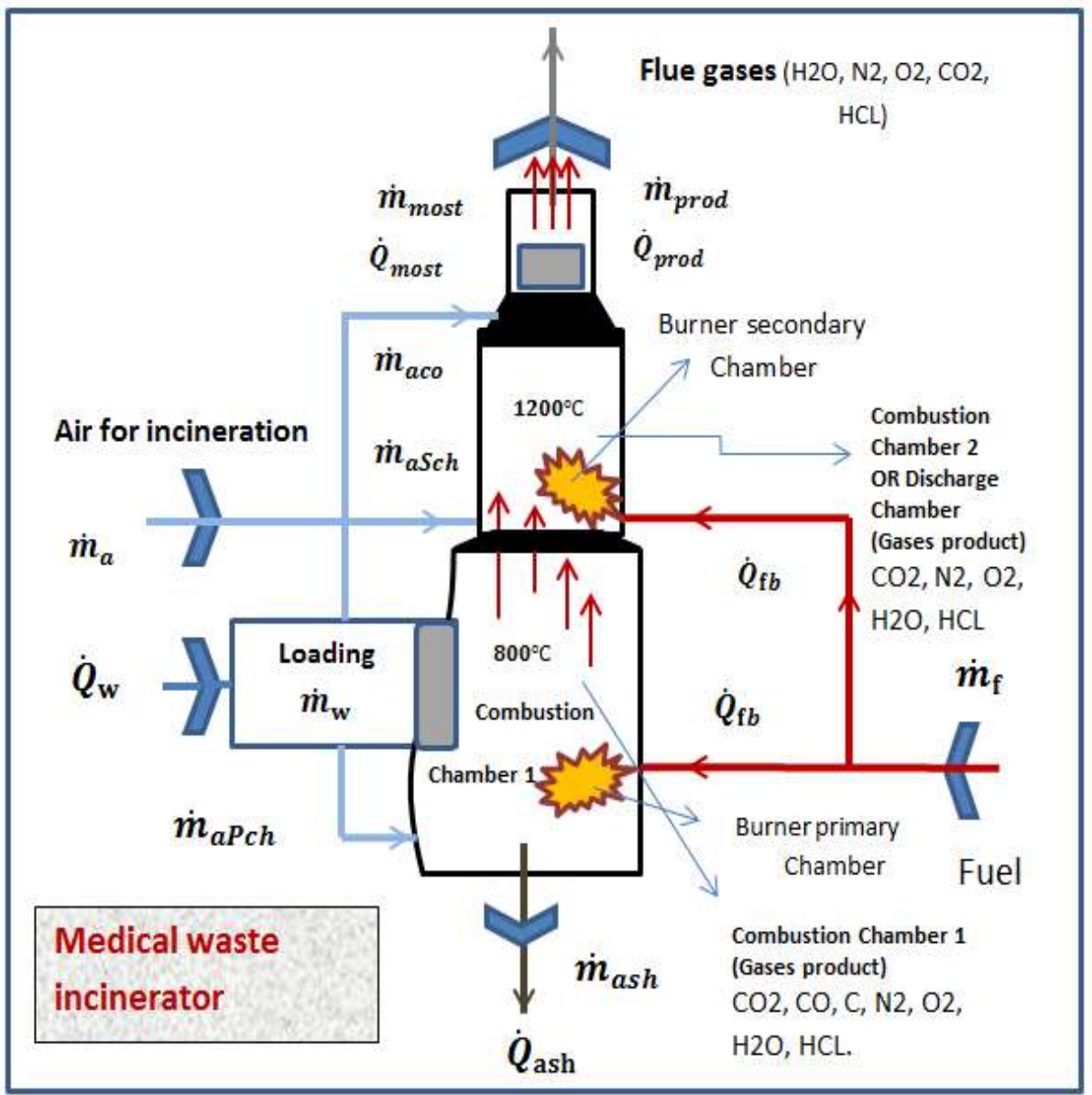

Fig. 1. System medical waste incinerators and the heat generated from incineration waste.

Technical parameters:

- $\quad$ Pch (Primary chamber) temperature reaches $800^{\circ} \mathrm{C}$ and Sch (Secondary chamber) temperature reaches $1200^{\circ} \mathrm{C}$. 
- The residence time for gases resulting from the combustion in the Sch is two seconds.

- $\quad$ The (Pch) is fed with $30 \%$ air of the required air.

- The air in the (Sch) supplied $150 \%$ of the air required at the peak combustion.

- Incinerators are made of refractory materials, and the combustion chambers are well insulated to maintain temperatures [11].

- $\quad$ Burners in the $(\mathrm{Pch})$ and the $(\mathrm{Sch})$ are fuelled with diesel fuel at $15 \mathrm{~kg}$ per hour.

- There are no air pollution control devices and no filter bags in the chimney.

\subsection{Thermal processes inside a medical waste incinerator}

The Medical Waste (MW) incineration process divided into:

Drying. When the heat vaporizes, superficial water and inherent water in the combustion chamber, the drying stage divide to: conduction drying, convection drying and radiation drying achieved by heat transfer. Whereas the higher the water content of the MW, accompanied by longer the drying phase will be consumed more thermal energy, and the temperature will be reduced and subsequently affecting the burning process.

Decomposition and thermal volatilization of combustible materials in MW generates many volatile hydrocarbons and carbon capture products. The pyrolysis reaction consists of endothermic and exothermic reactions. The thermal decomposition speed is related to the combustible components' composition, heat and mass transfer rate, and the organic solids' particle size.

Combustion. Gaseous and solid combustible substances resulting from drying and thermal decomposition, insufficient contact with air in the incinerator become a flame and start combustion at high temperatures. Therefore, MW burning is a mixed gas-phase combustion process and heterogeneous combustion, which is more complex than gaseous fuels and liquid fuels [12].

\subsection{Heat and Material Balance}

Heat and material balance calculation is an integral part of designing and evaluating incinerators. This technique involves a detailed estimation of the input and output conditions of the incinerator and to determine the combustion air and auxiliary fuel requirements for incinerating a given medical waste and determining an existing incinerator's limitations when charged with a known waste [12][13]. The characterization of biomedical waste is described extensively in [13]. The figure below (Fig 2) shows the different types of waste and the properties of hospitals biomedical waste in yellow bags. The steps to calculate the heat and material balance sample are presented below.

\subsubsection{Heating values of input material}

The material flow per hour into the incinerator is $100 \mathrm{~kg} / \mathrm{h}$. Based on an input waste, yellow bags waste is assumed to have the composition, according to the Table 1 and as shown in Figure 2 as well to consist of dry tissue, polyethylene, polyvinylchloride, cellulose, water, and ash represents $10,45,3,30,2,10 \mathrm{~kg} / \mathrm{h}$ respectively. 


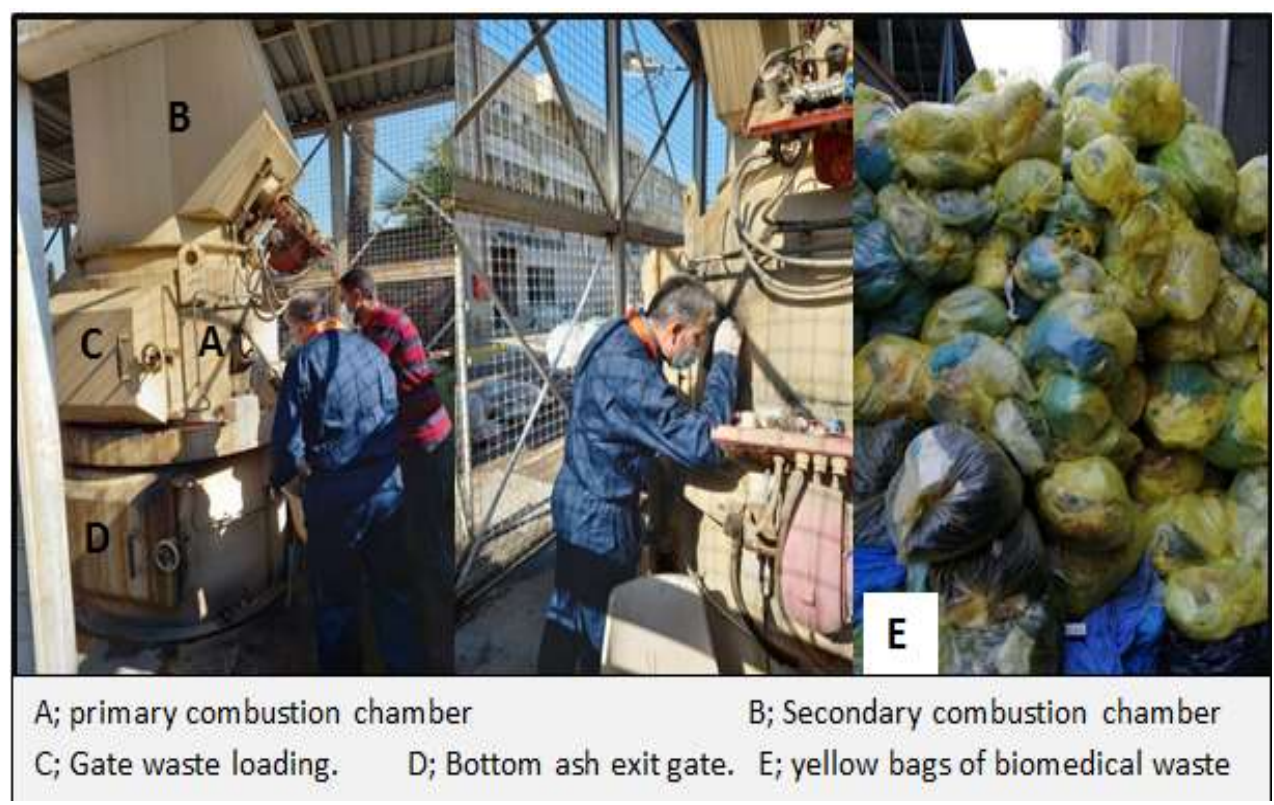

Fig. 2 The shape of incinerator and biomedical waste

Table 1. Higher heating values and total heat of the combustible medical waste

\begin{tabular}{|c|c|c|c|c|c|c|}
\hline Compound & $\begin{array}{l}\text { Chemical } \\
\text { Composition }\end{array}$ & $\begin{array}{l}\text { Molecular } \\
\text { Weight }\end{array}$ & $\begin{array}{l}\text { Fraction } \\
\text { assume }\end{array}$ & $\begin{array}{l}\text { Generation } \\
(\mathrm{kg} / \mathrm{h})\end{array}$ & $\begin{array}{c}\text { Calorific } \\
\text { Value } \\
(\mathrm{HHV}) \\
(\mathrm{kJ} / \mathrm{kg})\end{array}$ & $\begin{array}{l}\text { Total } \\
\text { heat } \\
(\mathrm{kJ} / \mathrm{h})\end{array}$ \\
\hline Tissue & $\mathrm{C}_{5} \mathrm{H}_{10} \mathrm{O}_{3}$ & 118.1 & 0.10 & $0.10 * 100=10$ & 20,471 & 204,710 \\
\hline $\begin{array}{c}\text { Plastic } \\
\text { (Polyethylene } \\
-96 \% \text { ) }\end{array}$ & $\left(\mathrm{C}_{2} \mathrm{H}_{4}\right)_{\mathrm{x}}$ & 28.1 & 0.45 & $0.45 * 100=45$ & 46,304 & 2083680 \\
\hline PVC & $\left(\mathrm{C}_{2} \mathrm{H}_{3} \mathrm{CL}\right)_{\mathrm{x}}$ & 62.5 & 0.03 & $0.03 * 100=3$ & 22,630 & 67,890 \\
\hline $\mathrm{H}_{2} \mathrm{O}$ & $\mathrm{H}_{2} \mathrm{O}$ & 18.0 & 0.02 & $0.02 * 100=2$ & 0 & 0 \\
\hline Ash & - & - & 0.10 & $0.10 * 100=10$ & 0 & 0 \\
\hline \multicolumn{3}{|c|}{$\begin{array}{l}\text { Total heat generation } \\
\text { from yellow waste bag }\end{array}$} & \multicolumn{2}{|r|}{100} & \multicolumn{2}{|r|}{2913320} \\
\hline
\end{tabular}

\subsubsection{Determination of stoichiometric oxygen for combustible medical wastes and combustion air rates}

The total theoretical amount of oxygen required to burn the waste determined by the chemical equilibrium equations of the biomedical waste's components from laboratory analysis, the theoretical oxygen to burn the medical waste's combustible component (100 $\mathrm{kg} / \mathrm{h}$ ). We can calculate the total requirements for the theoretical amount of oxygen required to burn (oxidize) the waste [3]. 
Table 2. Material chemical composition

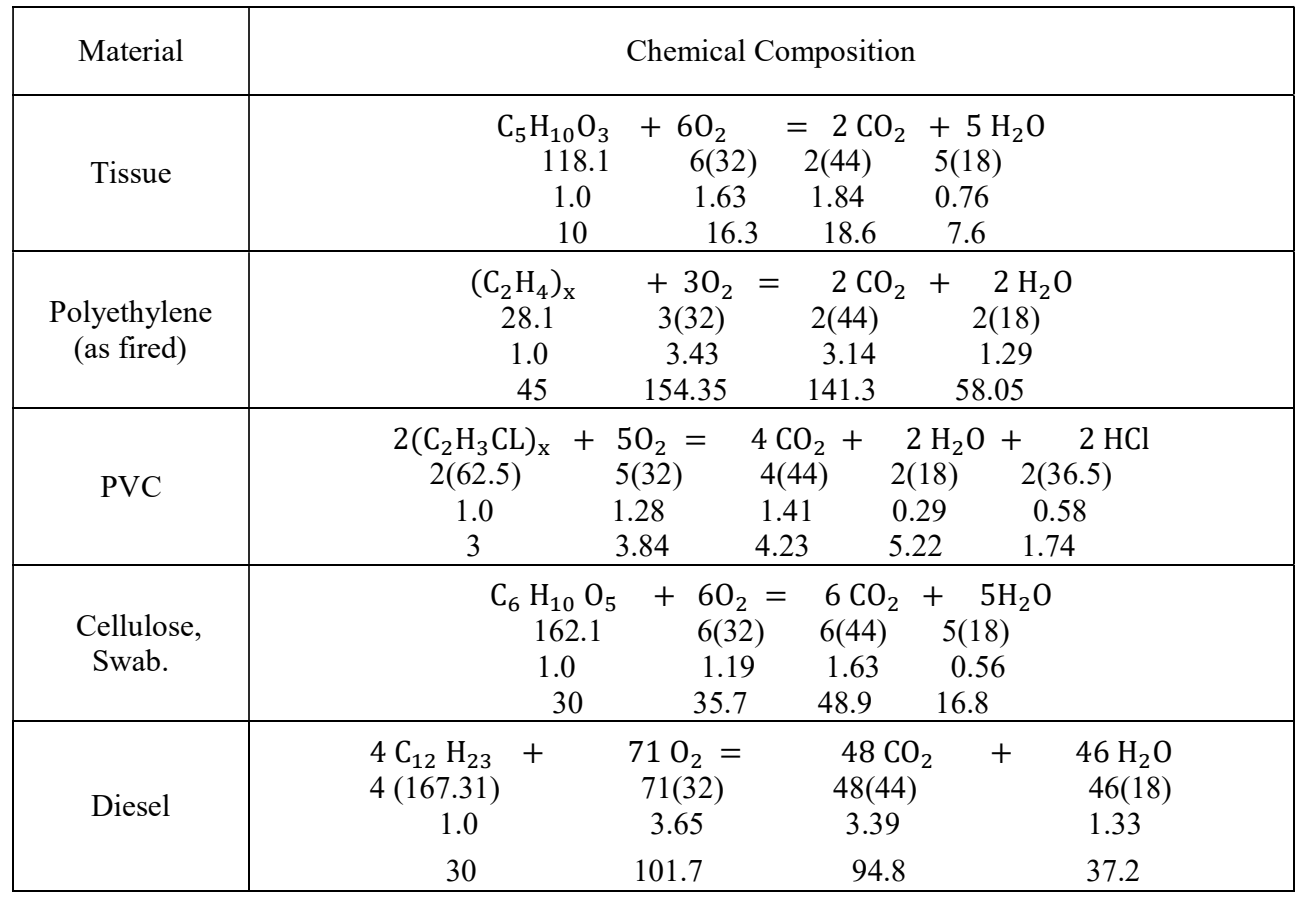

Total combustible components of waste $(\mathrm{kg} / \mathrm{h})=10+30+3+45=88(\mathrm{~kg} / \mathrm{h})$.

The total amount of oxygen required for stoichiometry of waste incineration generated per hour $=16.3+154.35+3.84+35.7+101.7=311.89(\mathrm{~kg} / \mathrm{h})$.

The stoichiometric air is calculated $=311.89 *(100 / 23)=1356.04(\mathrm{~kg} / \mathrm{h})$

Air is supplying two combustion chambers, where the first is supplied, with $30 \%$ of the air required for complete combustion of waste.

Air required primary chamber $=(0.30 * 311.89)+311.89=1762.85(\mathrm{~kg} / \mathrm{h})$

In the secondary chamber for combustion, excess air supplied to $150 \%$ of what is theoretically required [14].

Air excess secondary chamber $=(1.5 * 311.89)+311.89=3390.12(\mathrm{~kg} / \mathrm{h})$

\subsubsection{Material balance for combustion chambers}

A) Total mass input $\dot{\mathrm{m}}_{\mathrm{i}}(\mathrm{kg} / \mathrm{h})$

Mass Input, Waste Input Rate $\left(\dot{\mathrm{m}}_{\mathrm{W}}\right)=100 \mathrm{~kg} / \mathrm{h}$

Dry air $\left(\dot{\mathrm{m}}_{\mathrm{asch}}\right)=3390.12(\mathrm{~kg} / \mathrm{h})$

Moisture in air $\left(\dot{\mathrm{m}}_{\text {amoist }}\right)=0.0132 * 3390.12=44.75(\mathrm{~kg} / \mathrm{h})$

$\dot{\mathrm{m}}_{\text {diesel }}=15+15=30(\mathrm{~kg} / \mathrm{h})$

Total Mass input $\dot{\mathrm{m}}_{\mathrm{i}}=\dot{\mathrm{m}}_{\mathrm{w}}+\dot{\mathrm{m}}_{\mathrm{asch}}+\dot{\mathrm{m}}_{\text {amoist }}+\dot{\mathrm{m}}_{\text {diesel }}$ $\dot{\mathrm{m}}_{\mathrm{i}}(\mathrm{kg} / \mathrm{h})=100+3390.12+44.75+30=3564.86(\mathrm{~kg} / \mathrm{h})$

B) Total Mass Output (under the condition of complete combustion) $\dot{m}_{\mathrm{o}} \mathrm{k}, \mathrm{h}$.

1- Dry Products from Waste.

Air requirement for Waste $=3390.12(\mathrm{~kg} / \mathrm{h})$

Subtracting Stoichiometric air requirement $=1356.04(\mathrm{~kg} / \mathrm{h})$

Total excess air $\left(\dot{\mathrm{m}}_{\text {a.exces }}\right)=3390.12-1356.04=2034.07$ 
The nitrogen from stoichiometric air $(77 \%)=0.77 * 1356.04=1044.15 \mathrm{~kg} / \mathrm{h}$

Total production $=2034.07+1044.15=3078.22 \mathrm{~kg} / \mathrm{h}$.

The total $\mathrm{CO}_{2}$ from the combustion to determine the theoretical air required only

$\mathrm{CO}_{2}$ formed from $\mathrm{C}_{5} \mathrm{H}_{10} \mathrm{O}_{3}=18.6 \mathrm{~kg} / \mathrm{h}$.

$\mathrm{CO}_{2}$ formed from $\left(\mathrm{C}_{2} \mathrm{H}_{4}\right)_{\mathrm{x}}=141.3 \mathrm{~kg} / \mathrm{h}$.

$\mathrm{CO}_{2}$ formed from $2\left(\mathrm{C}_{2} \mathrm{H}_{3} \mathrm{Cl}\right)_{\mathrm{x}}=4.23 \mathrm{~kg} / \mathrm{h}$.

$\mathrm{CO}_{2}$ formed from $\mathrm{C}_{6} \mathrm{H}_{10} \mathrm{O}_{5}=48.9 \mathrm{~kg} / \mathrm{h}$.

$\mathrm{CO}_{2}$ formed from $4 \mathrm{C}_{12} \mathrm{H}_{23} \quad=94.8 \mathrm{~kg} / \mathrm{h}$

Total $\mathrm{CO}_{2}$ generated $\quad=307.83 \mathrm{~kg} / \mathrm{h}$.

Total Waste Dry products $\left(\dot{\mathrm{m}}_{\text {prod }}\right)=3078.22+307.83=3386.05 \mathrm{~kg} / \mathrm{h}$

The $\mathrm{CO}_{2}$ will be released to the ambient after complete combustion

2- Moisture $\left(\mathrm{H}_{2} \mathrm{O}\right)$

$\mathrm{H}_{2} \mathrm{O}$ Moisture in the waste $=2 \mathrm{~kg} / \mathrm{h}$.

$\mathrm{H}_{2} \mathrm{O}$ Moisture generated from Combustion reactions $=124.87 \mathrm{~kg} / \mathrm{h}$.

$\mathrm{H}_{2} \mathrm{O}$ Moisture in combustion air $=44.75 \mathrm{~kg} / \mathrm{h}$.

Total mass moisture $\left(\dot{\mathrm{m}}_{\text {moist }}\right)=2+124.87+44.75=171.62 \mathrm{~kg} / \mathrm{h}$.

3- Ash from combustion waste.

Total Ash output $\left(\dot{\mathrm{m}}_{\mathrm{ash}}\right)=10 \mathrm{~kg} / \mathrm{h}$.

4- $\mathrm{HCl}$ generation from Waste (PVC).

$\mathrm{HCl}$ from $2\left(\mathrm{C}_{2} \mathrm{H}_{3} \mathrm{Cl}\right)_{\mathrm{x}}=1.74 \mathrm{~kg} / \mathrm{h}$.

Total Mass Out $=$ Total waste dry products + Total moisture + Total $\mathrm{CO}_{2}$ from combustion $+\mathrm{HCl}$ formed from waste + Ash Output

Total Mass Output $\dot{\mathrm{m}}_{\mathrm{o}}(\mathrm{kg} / \mathrm{h})=3386.05+171.62+10+1.74=3569.41$ $\mathrm{kg} / \mathrm{h}$

Net mass balance $=\left(\dot{\mathrm{m}}_{\mathrm{i}}-\dot{\mathrm{m}}_{\mathrm{o}}\right)=3564.86-3569.41=4.55 \mathrm{~kg} / \mathrm{h}$

\subsubsection{Arithmetic balancing of the incinerator energy.}

Total heat generation from medical waste incineration $\left(\mathrm{Q}_{\mathrm{i}} \mathrm{kJ} / \mathrm{h}\right)$

Total heat generation from the yellow waste bag $\left(Q_{\mathrm{w}}=2913320 \mathrm{~kJ} / \mathrm{h}\right)$ from table 1 Add heat burner primary chamber and secondary chamber from medical waste incinerator The calorific value of diesel fuel is $45.5 \mathrm{MJ} / \mathrm{kg}=45500 \mathrm{~kJ} / \mathrm{kg}$

$$
\begin{aligned}
& \dot{\mathrm{m}}_{\mathrm{fbpch}}=15 \mathrm{~kg} / \mathrm{h} \\
& \dot{\mathrm{m}}_{\mathrm{fbsch}}=15 \mathrm{~kg} / \mathrm{h}
\end{aligned}
$$

Total heat generation from 2 burners $\mathrm{Q}_{\mathrm{tfb}} \mathrm{kJ} / \mathrm{h}=30 * 45500=1365000 \mathrm{~kJ} / \mathrm{h}$ $\mathrm{Q}_{\mathrm{tfb}}=1365000 \mathrm{~kJ} / \mathrm{h}$

$$
Q_{\mathrm{i}}(\mathrm{kJ} / \mathrm{h})=\mathrm{Q}_{\mathrm{w}}+\mathrm{Q}_{\mathrm{tfb}}=2913320+1365000=4278320 \mathrm{Kj}
$$

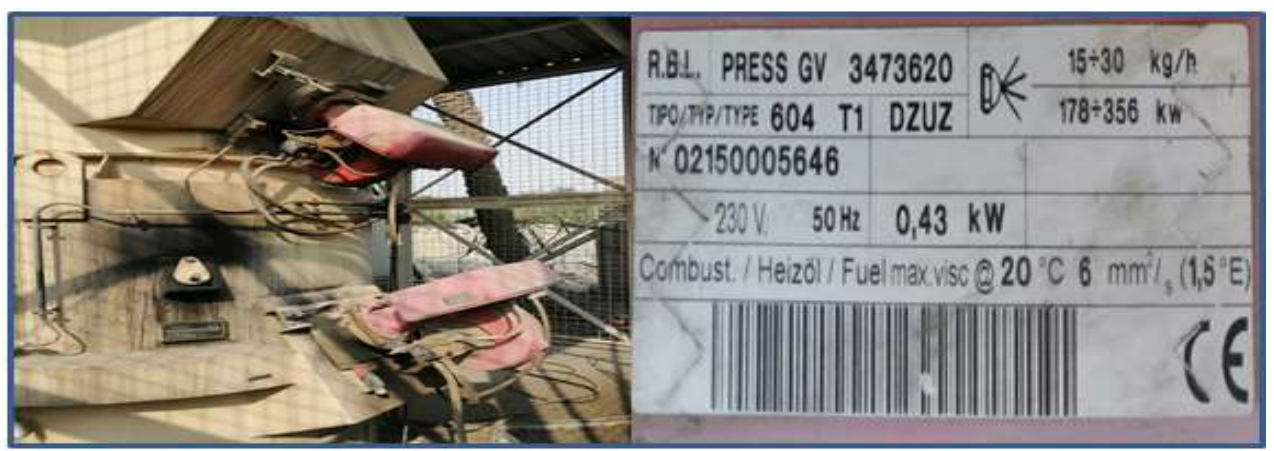

Fig. 3 Characteristics of the burner used in the two combustion chambers 
a) Radiation losses $=5 \%$ (of the heat produced from the yellow waste bag burning theat produce from 2 burners)[13]. Radiation heat loss generation from waste:

$\mathrm{Q}_{\mathrm{Rad}}=0.05 * 4278320=213916 \mathrm{~kJ} / \mathrm{h}$

b) Ash heat rate:

$$
\dot{Q}_{\mathrm{ash}}=\dot{m}_{\mathrm{ash}} C p \Delta T[15]
$$

Where:

$\dot{\mathrm{m}}_{\text {ash }}-$ mass of ash $=10 \mathrm{~kg} / \mathrm{h}$

$\mathrm{Cp}-$ for ash $=0.831 \mathrm{~kJ} / \mathrm{kg}^{\circ} \mathrm{C}$

$\Delta \mathrm{T}-$ Temperature difference $=\left(1200^{\circ} \mathrm{C}-20^{\circ} \mathrm{C}\right)=1180^{\circ} \mathrm{C}$

$\dot{\mathrm{Q}}_{\mathrm{ash}}=10 * 0.831 * 1180=9805.8 \mathrm{~kJ} / \mathrm{h}$

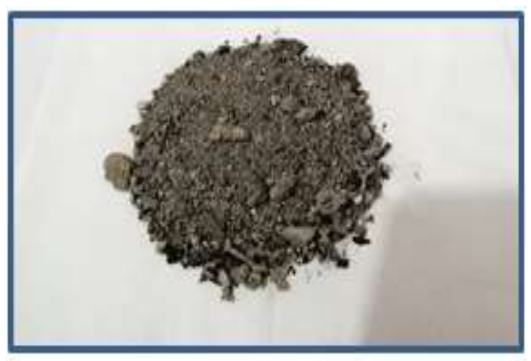

Fig. 4 Sample of bottom ash remaining from waste incineration.

c) Heat to dry combustion Products:

$$
\dot{Q}_{\text {prod }}=\dot{m}_{\mathrm{dpro}} C p \Delta T
$$

Where:

$\dot{\mathrm{m}}_{\text {dpro }}=\left(\dot{\mathrm{m}}_{\mathrm{a} \text { exces }}+\dot{\mathrm{m}}_{\mathrm{tco} 2}\right) \mathrm{kg} / \mathrm{h}$

$\dot{\mathrm{m}}_{\text {dpro }}$; mass waste dry products $\mathrm{kg} / \mathrm{h}=2034.07+307.83=2341.90 \mathrm{~kg} / \mathrm{h}$

$\dot{\mathrm{m}}_{\text {a.exces }}$; Total excess air $\mathrm{kg} / \mathrm{h}=2034.07 \mathrm{~kg} / \mathrm{h}$

$\dot{\mathrm{m}}_{\text {tco2}}$; Total CO2 generated $\mathrm{kg} / \mathrm{h}=307.83 \mathrm{~kg} / \mathrm{h}$

$\mathrm{Cp}-$ for dry products $=1.086 \mathrm{~kJ} / \mathrm{kg}{ }^{\circ} \mathrm{C}$

$\Delta \mathrm{T}$ - Temperature difference $=(1200-20){ }^{\circ} \mathrm{C}=1180{ }^{\circ} \mathrm{C}$

$\dot{\mathrm{Q}}_{\text {prod }}=2341.90 * 1.086 * 1180=3001098.01 \mathrm{~kJ} / \mathrm{h}$

d) Heat to moisture

$$
\dot{Q}_{\text {moist }}=\dot{m}_{\text {moist }} C p \Delta T+\dot{m}_{\text {moist }} H v[12][13]
$$

Where:

$\dot{\mathrm{m}}_{\text {moist }}-$ Total mass moisture $=171.62 \mathrm{~kg} / \mathrm{h}$

$\mathrm{Cp}-$ Water heat capacity const. $=2.347 \mathrm{~kJ} / \mathrm{kg} .{ }^{\circ} \mathrm{C}$

$\Delta \mathrm{T}$ - Temperature difference $=(1200-20){ }^{\circ} \mathrm{C}=1180{ }^{\circ} \mathrm{C}$

$\mathrm{H}_{\mathrm{v}}-$ Water vapor latent heat const. $=2460.3 \mathrm{~kJ} / \mathrm{kg}$

$\dot{\mathrm{Q}}_{\text {moist }}=171.62 * 2.347 * 1180+171.62 * 2460.3=897531.4 \mathrm{~kJ} / \mathrm{h}$

Total Heat output:

$$
\dot{Q}_{\mathrm{o}}=\dot{Q}_{\mathrm{Rad}}+\dot{Q}_{\mathrm{ash}}+\dot{Q}_{\mathrm{prod}}+\dot{Q}_{\mathrm{moist}}
$$


$\dot{\mathrm{Q}}_{\mathrm{o}}=21396+9805.80+3001098.01+897531.40=3929831.21 \mathrm{~kJ} / \mathrm{h}$

Net Heat Balance $=\left(\dot{Q}_{\mathrm{i}}-\dot{\mathrm{Q}}_{\mathrm{o}}\right) \mathrm{kJ} / \mathrm{h}=4278320-3929831.21=348488.79 \mathrm{~kJ} / \mathrm{h}$

\subsubsection{Efficiency of the Machine.}

$$
\begin{array}{r}
\eta_{\text {incinerator }}=\frac{\text { Energy output }}{\text { Energy input }}=\frac{\dot{Q}_{\mathrm{o}}}{\dot{Q}_{\mathrm{i}}} \\
\eta_{\text {incinerator }}=\frac{3929831.21}{4278320}=91.85 \%
\end{array}
$$

\section{Conclusion}

The experiment calculates the heat, mass and energy from the incineration of medical waste using a double-stage diesel furnace and the effect of recovering the positive thermal energy generated from the incineration of the waste component. Could use the heat generated from waste burning to heating water that supplies the hospital; this system is more valuable with a large waste quantity.

The theoretical calculations for an incinerator located in one of Baghdad hospitals, in the Medical City, and the temperatures were constant in the burning: $800^{\circ} \mathrm{C}-1200^{\circ} \mathrm{C}$ for the primary and secondary chamber. Our reading was depending on actual waste which daily collected from the hospital and diesel consumption.

The inputs and outputs of waste, air, and fuel studied were close to the standard range. The heat generated is compared to the energy produced by the burners in the combustion chambers the energy of medical waste. The result was a very small difference due to the amount of diesel fuel consumed for the burners or heat loss in the insolation area.

As per the experiment, medical waste incinerators are appropriate for treating waste, reducing its volume and weight, purifying it, and recovering useful energy.

\section{References}

1. World Health Organisation et al., "Safe management of wastes from health-care activities," $\quad$ p. 329, 2014, [Online]. Available: http://apps.who.int/iris/bitstream/10665/85349/1/9789241548564_eng.pdf.

2. M. S. Arti Pamnani, "Muncipal solid waste management in India: A review and some new results," I.J. Civ. Eng. Technol., vol. 5, no. 2, pp. 1-8, (2014).

3. E. Okechukwu, C. Chukwutoo, and E. Chibundo, "Theoretical design of a nonenergy recovery incinerator for awka municipality," JEAS, vol. 13, pp. 154-166, (2018).

4. H. A. A. Salam, "Operating and emission characterstics of a novel design four chambers infectious meat incinerator," IJRET pp. 322-328, (2013).

5. D. T. Lup, A. M. Stroe, P. M. Chezan, E. Pica, "The importance of waste incineration," Studia Universitatis Babeș-Bolyai Ambientum, 63. pp. 43-48, (2018), doi: 10.24193/subbambientum.2018.1.04.

6. R. O. Adu, S. F. Gyasi, D. K. Essumang, and K. B. Otabil, "Medical WasteSorting and Management Practices in Five Hospitals in Ghana," J. Environ Public Health, vol. 2020, (2020). 
7. Y. Yang, H. Wang, K. Chen, J. Zhou, S. Deng, and Y. Wang, "Shelter hospital mode: How do we prevent COVID-19 hospital-acquired infection?," I. C. H. Ep., vol. 41, no. 7, pp. 872-873, (2020), doi: 10.1017/ice.2020.97.

8. S. Request, T. O. Fogarty, P. Feel, F. To, D. To, and P. Interested, "Small-scale Medical Waste Incinerators: Evaluation of Risks and Best Management Practices," no. October 2003, pp. 55-65, (2004).

9. F. Lombardi, E. Lategano, S. Cordiner, and V. Torretta, "Waste incineration in rotary kilns: A new simulation combustion tool to support design and technical change," Waste Manag. Res., vol. 31, no. 7, pp. 739-750, (2013), doi: $10.1177 / 0734242 X 13484187$.

10. J. Wajs, R. Bochniak, and A. Golabek, "Proposal of a mobile medical waste incinerator with application of automatic waste feeder and heat recovery system as a novelty in Poland," Sustain., vol. 11, no. 18, (2019), doi: $10.3390 /$ su11184980.

11. O. O. Olanrewaju and R. J. Fasinmirin, "Design of Medical Wastes Incinerator for Health Care Facilities in Akure," J. Eng. Res. Reports, vol. 5, no. 2, pp. 1-13, (2019), doi: 10.9734/jerr/2019/v5i216919.

12. J. Shiju Easo and C. Nanjunda Swamy, "Design of incinerator for the treatment of bio-medical solid waste in chikmagalur city," J. Ind. Pollut. Control, vol. 27, no. 2, pp. 173-179, (2011).

13. R. Ganguly, P. Vasistha, and A. K. Gupta, "Design of an incinerator to treat combined biomedical wastes generated from four major hospitals in Chandigarh and Shimla City, India," Res. J. Pharm. Biol. Chem. Sci., vol. 8, no. 3S, pp. 201212, (2017).

14. R.Walter and S.P. Niessen, "Combustion and incineration processes," 4th Edition., (2010).

15. R. K. Patel, “Design of Biomedical Waste Incinerator,” Int. J. Res. Appl. Sci. Eng. Technol., vol. V, no. IX, pp. 436-442, (2017), doi: 10.22214/ijraset.2017.9064. 